\title{
Mammary gland zinc metabolism: regulation and dysregulation
}

\author{
Shannon L. Kelleher · Young Ah Seo • \\ Veronica Lopez
}

Received: 31 October 2008/Accepted: 17 March 2009/Published online: 2 April 2009

(C) Springer-Verlag 2009

\begin{abstract}
Zinc (Zn) is required for numerous metabolic processes serving both a structural and catalytic role. The mammary gland has a unique $\mathrm{Zn}$ requirement resulting from the need to also transfer an extraordinary amount of $\mathrm{Zn}$ into milk ( $\sim 0.5-1 \mathrm{mg} \mathrm{Zn} /$ day) during lactation. Impairments in this process can result in severe $\mathrm{Zn}$ deficiency in the nursing offspring which has adverse consequences with respect to growth and development. Moreover, dysregulated mammary gland $\mathrm{Zn}$ metabolism has recently been implicated in breast cancer transition, progression and metastasis, thus there is a critical need to understand the molecular mechanisms which underlie these observations. Tight regulation of $\mathrm{Zn}$ transporting mechanisms is critical to providing an extraordinary amount of $\mathrm{Zn}$ for secretion into milk as well as maintaining optimal cellular function. Expression of numerous $\mathrm{Zn}$ transporters has been detected in mammary gland or cultured breast cells; however, understanding the molecular mechanisms which regulate mammary $\mathrm{Zn}$ metabolism as well as the etiology and downstream consequences resulting from their dysregulation is largely not understood. In this review, we
\end{abstract}

\section{S. L. Kelleher $(\square)$}

Department of Nutritional Sciences, The Pennsylvania State University, 222 Chandlee Laboratory, University Park,

PA 16802, USA

e-mail: slk39@psu.edu

\section{Y. A. Seo}

Department of Nutritional Sciences, The Pennsylvania State University, 209 Chandlee Laboratory, University Park, PA 16802, USA

\section{Lopez}

Department of Nutritional Sciences, The Pennsylvania State University, 220 Chandlee Laboratory, University Park, PA 16802, USA will summarize the current understanding of the regulation of mammary gland $\mathrm{Zn}$ metabolism and its regulation by reproductive hormones, with a discussion of the dysregulation of this process in breast cancer.

Keywords Breast cancer - Estrogen - Lactation · Mammary gland $\cdot$ Prolactin $\cdot$ Zinc transporter

\section{Introduction}

Zinc $(\mathrm{Zn})$ is the second most abundant trace element in the human body [105]. As an essential mineral, $\mathrm{Zn}$ is required for numerous metabolic processes including the regulation of many proteins involved in DNA and protein synthesis, mitosis and cell division serving both a structural and catalytic role. In addition to regulating basic cellular function, tight regulation of $\mathrm{Zn}$ transport in the mammary gland is critical for optimal $\mathrm{Zn}$ transfer into milk during lactation. Adequate $\mathrm{Zn}$ transfer into milk is particularly important as neonatal $\mathrm{Zn}$ requirements are high during this period of rapid growth and development and $\mathrm{Zn}$ deficiency in infants results in impaired immune function and decreased growth. In addition, dysregulation of mammary gland $\mathrm{Zn}$ metabolism has recently been associated with breast cancer. Recent epidemiological studies have illustrated a relationship between high breast tissue $\mathrm{Zn}$ levels and breast cancer [19]. Unfortunately, the link between the regulation of $\mathrm{Zn}$ homeostasis and breast cancer has been thus far indirect; however, the limited information available supports the postulate that dysregulation of $\mathrm{Zn}$ metabolism may be associated with aberrant cellular function and cancer progression. Thus, tight regulation of $\mathrm{Zn}$ transporting mechanisms is critical to providing an extraordinary amount of $\mathrm{Zn}$ for secretion into milk as well 


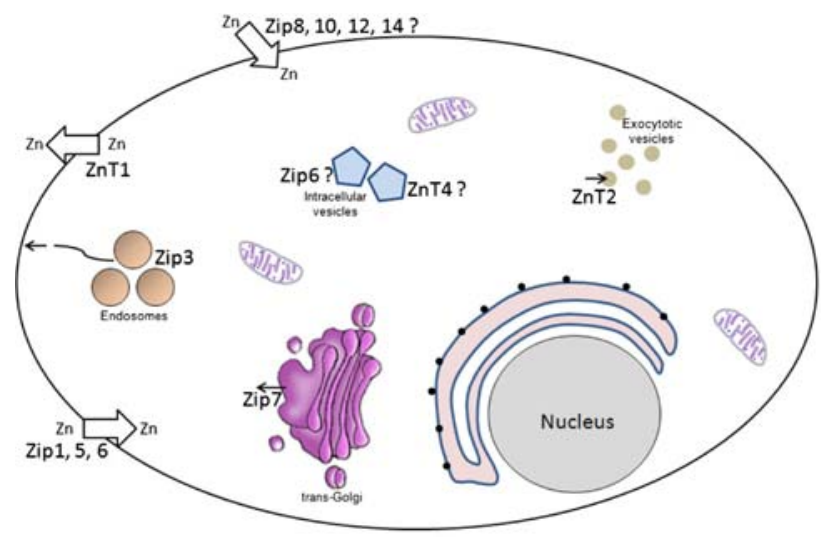

Fig. 1 Zinc transporting proteins expressed in mammary epithelial cells. Members of the SLC39A family (Zip1-14) import Zn into the cytoplasm, either across the plasma membrane or out of an intracellular compartment. Members of the SLC30A family (ZnT110) are responsible for $\mathrm{Zn}$ export from the cytoplasm, either across the plasma membrane into the extracellular milieu or into intracellular compartments or organelles

as maintaining optimal cellular function in the mammary gland.

Tremendous progress has been made over the past decade with respect to improving our understanding of how $\mathrm{Zn}$ transport is regulated at the cellular and physiological level. Currently, $24 \mathrm{Zn}$ transporters have been identified and many have been at least preliminarily characterized as to their role in $\mathrm{Zn}$ transport across membranes [25, 47, 75]. Zinc transporters are divided into two distinct gene families (SLC3OA and SLC39A) and expression of numerous $\mathrm{Zn}$ transporters has been detected in the mammary gland or in cultured mammary cells (Fig. 1). Unfortunately, there is a paucity of information regarding their functional role in mammary gland $\mathrm{Zn}$ metabolism or their regulation in this unique tissue. Members of the ZnT family (ZnT1-10), with the exception of ZnT5 [46], are predicted to be structurally similar, having six transmembrane domains with a histidine-rich domain that is believed to play a key role in $\mathrm{Zn}$ binding [88]. ZnT proteins function to transport $\mathrm{Zn}$ from the cytosol, either into the exoplasmic space or into intracellular vesicles. Expression of ZnT1, ZnT2, and ZnT4 has been detected in mammary tissue. ZnT1 is a ubiquitously expressed $\mathrm{Zn}$ exporter and expression is positively regulated by $\mathrm{Zn}$ exposure [56, 60]. ZnT1 has been localized to both intracellular compartment(s) and the plasma membrane [61]. It is presumed that this reflects intracellular trafficking of ZnT1 to multiple sub-cellular compartments; however, evidence suggests that $\mathrm{ZnT} 1$ isoforms may exist as tissue-specific expression of two ZnT1 mRNAs have been identified [60]. ZnT2 was first identified by Palmiter et al. [87]. Few studies have focused on its role in $\mathrm{Zn}$ transport which may reflect the restricted distribution to unique secretory tissues such as mammary gland $[49,50]$, prostate [40], and pancreas [62] under normal physiological conditions. Intracellular localization and a positive correlation between cellular Zn level and ZnT2 abundance has led to the suggestion that ZnT2 participates in vesicular $\mathrm{Zn}$ sequestration and perhaps export or secretion [62]. Similar to ZnT1, ZnT4 is also ubiquitously expressed but is localized to an intracellular, vesicular compartment [82]. Despite the fact that a truncation mutation in ZnT4 results in low milk Zn levels [38], ZnT4 may not co-localize with labile $\mathrm{Zn}$ pools [78] thus its contribution to maintaining milk $\mathrm{Zn}$ level is not understood. To our knowledge, expression of the remaining members of the $\mathrm{ZnT}$ family in the mammary gland has not yet been identified.

The second family of mammalian $\mathrm{Zn}$ transporters (Zip1-14) has been identified as a result of gene sequence homology with known Zn transporters (ZRT1, IRTl-like protein) found in plants and yeast [29]. Zip proteins have been shown to facilitate cellular $\mathrm{Zn}$ uptake in transfected cell models $[24,106]$. Members of this family can be subdivided into four sub-families based on sequence similarity [101] and share a 12 amino acid signature sequence (HSVFEGLAVGLQ) present in the putative fourth transmembrane domain. Thus far, expression of all Zip proteins with the exception of Zip4, Zip9 and Zip11 has been documented in mammary tissue or cultured mammary cells; however, their specific contribution to mammary gland $\mathrm{Zn}$ metabolism is not well understood. Zip1 is ubiquitously expressed and localized to the plasma membrane [22] or to intracellular compartments in a cell-specific manner [79]. In prostate Zip1 localizes primarily to the luminal (apical) membrane [20], which suggests its role in $\mathrm{Zn}$ import from systemic circulation is limited. Like several Zip proteins, Zip1 is rapidly endocytosed in response to $\mathrm{Zn}$ exposure [22] illustrating the reliance on post-translational regulation. Targeted deletion of the mouse ZIP1 gene illustrates that Zip1 is not biologically essential but does result in increased sensitivity to $\mathrm{Zn}$ deficiency [24]. Targeted deletion of the mouse ZIP3 gene revealed that it is not essential for viability and fertility and under normal growth conditions homozygous ZIP3 knockout mice exhibited no obvious phenotypic effect [23]. However, mice lacking Zip3 during pregnancy or at weaning showed impaired adaptation to $\mathrm{Zn}$ deficiency, suggesting that like Zip1, Zip3 plays an ancillary role during $\mathrm{Zn}$ deficiency and may transport several trace minerals other than $\mathrm{Zn}$ [24]. Zip5 expression has been detected in cultured human breast cells [102] although Zip5 function in this cell type has not been characterized. In enterocytes, Zip5 is localized to the basolateral membrane [107], where it likely imports $\mathrm{Zn}$ from systemic circulation. A novel aspect of Zip5 regulation is the documentation that while Zip5 transcription is not regulated by $\mathrm{Zn}$ exposure, Zip5 protein translation is Zn-responsive [107]. Zip6 (LIV-1) is primarily expressed in hormonally controlled 
tissues including the mammary gland, prostate and brain [14, 101, 102]. Zip6 was first identified as a putative marker for breast cancer although this relationship is not well understood. Immunohistochemistry of human breast biopsies indicates that Zip6 is localized to the plasma membrane and within an intracellular compartment [48]; however, the relevance of this observation to mammary gland $\mathrm{Zn}$ metabolism is not understood. Zip7 is a ubiquitously expressed transporter that exports $\mathrm{Zn}$ from the Golgi into the cytoplasm [39]. Similar to Zip5, Zip7 translation appears to be regulated by $\mathrm{Zn}$ exposure as opposed to transcriptional or post-translational mechanisms [39]. Zip8 expression has been documented in breast cancer cells and similar to Zip3, Zip8 is capable of importing other minerals including cadmium and manganese [37]. Zip8 expression and localization are responsive to $\mathrm{TNF}-\alpha$ suggesting a role in modulating inflammatory response [7]. Although expression of Zip10 and Zip12 has been detected in cultured breast cancer cells, little is known regarding their function or regulation. Studies indicate that Zip10 is positively regulated by thyroid hormones in intestine and kidney [90] and expression is positively correlated with invasive breast carcinomas [45]. Zip12 localization or function has not been delineated. Zip14 expression has also been detected in breast cancer cells [102]. Zip14 is alternatively spliced, giving rise to two isoforms Zip14A (primarily expressed in liver, duodenum, kidney, and testis) and Zip14B (primarily expressed in liver, duodenum, brain, and testis) [34]. Similar to Zip8, Zip14 transports iron [31] and cadmium as well as $\mathrm{Zn}$ and expression is upregulated by inflammation and LPS [59]. Similar to Zip12, Zip14 expression has been detected in MCF-7 human breast cancer cells [102] although the distinction between Zip14 isoform expression and function in the mammary gland has not yet been investigated.

Together the integration of $\mathrm{Zn}$ import, $\mathrm{Zn}$ sequestration and $\mathrm{Zn}$ export mechanisms in the mammary gland coordinates not only the secretion of optimal amounts of $\mathrm{Zn}$ into milk during lactation but also tightly controls intracellular $\mathrm{Zn}$ pools thus regulating cellular function. Understanding the mechanisms which regulate mammary gland $\mathrm{Zn}$ transport as well as the etiology and consequences of dysregulated $\mathrm{Zn}$ metabolism in breast tissue will provide critical knowledge regarding the complex regulation of $\mathrm{Zn}$ metabolism in highly specialized, hormonally responsive tissues and may ultimately yield important therapeutic interventions.

\section{Mammary gland zinc metabolism and lactation}

To provide optimal $\mathrm{Zn}$ to the offspring, the mammary gland must import a substantial amount of $\mathrm{Zn}$ from maternal circulation and then secrete it into milk $(0.5-1 \mathrm{mg}$ $\mathrm{Zn}$ /day). This process facilitates the movement of almost twice the amount of $\mathrm{Zn}$ that is transferred daily across the placenta to the fetus during the third trimester of pregnancy [53] which illustrates the extraordinary capacity of the mammary gland for $\mathrm{Zn}$ transport. Moreover, milk $\mathrm{Zn}$ concentration is maintained over a wide range of dietary $\mathrm{Zn}$ intake [54, 81], which further suggests that mammary gland $\mathrm{Zn}$ import and export are tightly regulated in order to provide adequate $\mathrm{Zn}$ to the nursing infant. The essentiality of optimal $\mathrm{Zn}$ intake during the neonatal period is evidenced by observations of early neonatal death associated with low milk Zn levels in "lethal milk" (lm) mice [38]. Dysregulation of this process in humans also results in a condition referred to as "transient neonatal $\mathrm{Zn}$ deficiency" which results in severe $\mathrm{Zn}$ deficiency in the nursing infant. How the mammary gland is able to transport and regulate such extraordinary $\mathrm{Zn}$ transfer into milk to provide optimal $\mathrm{Zn}$ for neonatal growth and development is not well understood.

Emerging data suggests that this process is dependent upon the tight integration of $\mathrm{Zn}$ transporting mechanisms thus ensuring adequate $\mathrm{Zn}$ uptake into the mammary gland is coupled with optimal $\mathrm{Zn}$ secretion into milk. Studies exploring the role of several Zn transporters (Zip1, Zip3, ZnT1, ZnT2, and ZnT4) have provided preliminary information regarding the mechanisms that regulate milk $\mathrm{Zn}$ levels. Most of our understanding comes from studies conducted in lactating rodents or mammary cell models. Zip1 is expressed in the lactating mouse mammary gland, although it appears to primarily mediate $\mathrm{Zn}$ import across the luminal membrane from milk pooled within the alveolar lumen (Fig. 2), as has been observed in prostate [20]. This observation may reflect the lack of a $\mathrm{Zn}$ deficient phenotype in pups nursed from Zip1-null mice [23]. Our research group has used the mouse mammary epithelial cell line $\mathrm{HC} 11$ as a model system. HC11 cells, a clonal derivative of the mammary epithelial COMMA-1D cell line, are an excellent model for studying processes which are regulated by lactogenic hormones such as prolactin as they endogenously express prolactin receptors [21]. Studies in the mammary gland of the lactating rat and cultured HC11 cells, have detected expression of Zip3 and verified that it imports Zn [51, 52]. Interestingly, Zip3 is localized intracellularly in mammary cells but traffics to the plasma membrane in response to the lactogenic hormone prolactin to increase $\mathrm{Zn}$ uptake [51, 52]. The mechanisms responsible for prolactin-stimulated Zip3 trafficking have yet to be been delineated. The declining expression of Zip3 throughout lactation [50] in combination with a lack of phenotype noted in mice nursed from Zip3-null dams suggests Zip3 plays a minor role in mammary gland Zn uptake during lactation and illustrates that other Zip 


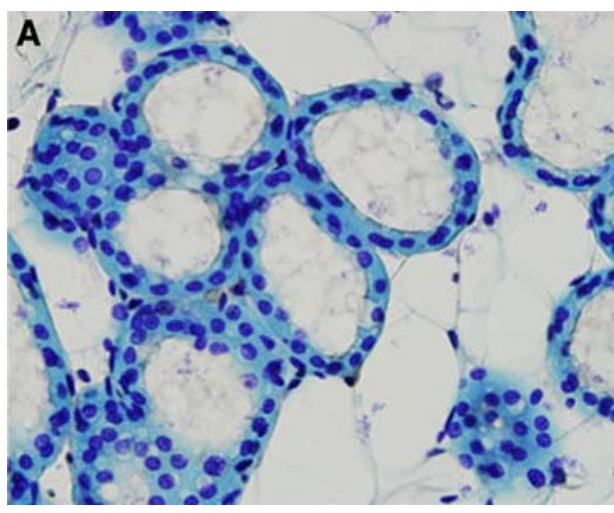

Fig. 2 Zip1 is primarily localized to the luminal membrane in lactating mouse mammary gland. Mouse mammary gland was fixed, embedded in paraffin and sectioned $(4 \mu \mathrm{m})$. Localization of Zip1 was detected using affinity purified Zip1 antibody and counterstained with

proteins likely play a role in $\mathrm{Zn}$ import from maternal circulation. While other Zip proteins are expressed in mammary cells $[101,102]$ little is known regarding their contribution to $\mathrm{Zn}$ accumulation in the mammary gland during lactation. Taken together, it is clear that our understanding of the mechanisms that regulate $\mathrm{Zn}$ import from maternal circulation is incomplete.

Expression of three $\mathrm{Zn}$ transporters which may play a role in intracellular $\mathrm{Zn}$ accumulation or $\mathrm{Zn}$ export from the lactating mammary gland has been characterized. Both ZnT1 mRNA expression and protein abundance increase through lactation and ZnT1 is appropriately localized to the luminal membrane, suggesting a role in $\mathrm{Zn}$ secretion into milk. However, increased ZnT1 expression occurs concomitant with a decline in milk $\mathrm{Zn}$ concentration [50]. This may be explained by the observation that $\mathrm{ZnT} 1$ associated with luminal membrane is particularly high during early lactation and is detected within the mammary cell as lactation continues. Expression of several $\mathrm{Zn}$ transporters that participate in intracellular $\mathrm{Zn}$ compartmentalization has been detected. ZnT2 is localized proximal to the luminal membrane of the mammary epithelial cell $[49,50,61]$. Association of ZnT2 with the luminal membrane also declines as lactation continues suggesting that $\mathrm{ZnT} 2$ plays a significant role in mediating the $\mathrm{Zn}$ transfer into milk during early lactation as well. We have recently determined that there are two functional ZnT2 isoforms which are localized to either the plasma membrane or exocytotic vesicles in mammary cells [66]. Similar to Zip3, ZnT2 expression is regulated by lactogenic hormones which we have recently documented at least in part, results from transcriptional regulation through prolactin signaling mechanisms [92]. ZnT4 is expressed ubiquitously, but abundantly expressed in mammary gland, brain and kidney [3, 4, 41, 49, 69]. ZnT4 is localized to intracellular vesicles and to the trans-Golgi network of normal rat kidney cells

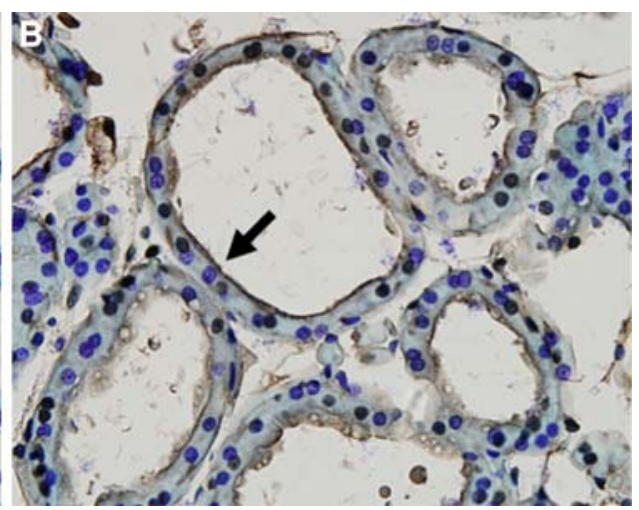

toluene blue; X60. Zip1 was not detected in the mammary gland of Zip1 knock-out mice (a) but was clearly visible associated with the luminal membrane in wild-type mice (b arrow)

[38]. In the mammary gland, ZnT4 was most abundant in cells surrounding the alveolar ducts [61] and resides in an intracellular compartment but does not co-localize with labile $\mathrm{Zn}$ pools but perhaps instead with milk-protein containing vesicles [78]. Currently the role of ZnT4 in milk $\mathrm{Zn}$ secretion is not understood despite the fact that a mutation in the gene that encodes ZnT4 (SLC30A4) is responsible for the "lethal milk" $\left(\mathrm{lm}^{-} / \mathrm{lm}^{-}\right)$phenotype which is associated with reduced $\mathrm{Zn}$ secretion into milk during lactation [38, 91]. Observations that milk from $\mathrm{lm}^{-} / \mathrm{lm}^{-}$mice still contains $\sim 50 \%$ of normal milk $\mathrm{Zn}$ concentration [1] and that pup survival can be improved by maternal $\mathrm{Zn}$ supplementation illustrate the complex redundancy in mammary gland $\mathrm{Zn}$ secretion mechanisms. Interestingly, localization might depend upon the stage of lactation as $\mathrm{ZnT} 4$ shifts its relative distribution from the luminal membrane during early lactation to more of a homogeneous intracellular distribution during late lactation possibly reducing its overall contribution to milk $\mathrm{Zn}$ secretion as lactation progresses.

\section{Dysregulation of zinc metabolism during lactation}

The importance of optimal mammary gland $\mathrm{Zn}$ transfer is recognized by a condition known as "transient neonatal $\mathrm{Zn}$ deficiency" that results in severe Zn deficiency in nursing infants [13] and the early death from severe $\mathrm{Zn}$ deficiency of pups suckled from "lethal milk" mice [38]. "Transient neonatal Zn deficiency" has been documented in both premature and term newborns [4]. Numerous case reports have documented this condition [2, 4, 77, 89, 108] as a consequence of low milk $\mathrm{Zn}$ concentration in nursing mothers, which cannot be corrected by maternal Zn supplementation [89, 108]. Term breast-fed infants with this condition usually experience severe eczema and decreased 
growth by 2-3 months of age; premature infants experience eczema and decreased growth earlier due to their lower $\mathrm{Zn}$ stores at birth [4]. "Transient neonatal $\mathrm{Zn}$ deficiency" resembles some aspects of the phenotype observed in "lethal milk" mice. However, "transient neonatal Zn deficiency" in humans is clinically distinct from symptoms in $\mathrm{lm}^{-} / \mathrm{lm} \mathrm{m}^{-}$mice in that no maternal symptoms, other than low breast milk Zn concentration, have been reported in affected humans, whereas $\mathrm{lm}^{-} / \mathrm{lm}^{-}$mice develop $\mathrm{Zn}$ deficiency with age and lack utricular otoconia, resulting in abnormalities in the balance system [27]. The mutation in SLC3OA4 which results in the "lethal milk" phenotype is presumed to result in early translational termination and truncation of the ZnT4 protein. Interestingly, Murgia et al. [83] determined that ZnT4 mRNA is absent in "lethal milk" mice, suggesting nonsense mediated decay as a secondary level of posttranscriptional control of ZnT4 mRNA in $\mathrm{lm}^{-} / \mathrm{lm}^{-}$mice. Numerous reports clearly demonstrate that this mutation is not responsible for "transient neonatal Zn deficiency" in human infants $[63,95]$. Recently we have found a family in which two exclusively breast-fed infants developed "transient neonatal $\mathrm{Zn}$ deficiency" that was associated with low milk $\mathrm{Zn}$ concentration in both women [13]. This condition was not associated with mutations in ZnT4 or Zip3 but did result from a mis-sense mutation in $\mathrm{ZnT} 2$ which substitutes an arginine for a conserved histidine residue (H54R) in the $\mathrm{N}$-terminal domain resulting in decreased $\mathrm{Zn}$ secretion from the mammary gland during lactation in the mothers of infants suffering from this condition. The incidence and penetrance of this mutation are currently unknown. Together, observations gleaned from studies documenting mutations in ZnT4 and ZnT2 illustrates a role for at least $\mathrm{ZnT} 2$ and ZnT4 in facilitating Zn secretion into milk.

\section{Regulation by the lactogenic hormone prolactin}

The mammary gland is comprised of numerous cell types including mammary epithelial cells which are highly specialized secretory cells that line an alveolar lumen and are responsible for the synthesis and/or secretion of milk components. These cells tightly coordinate the accumulation, production and secretion of milk components in a vectorial manner. This process requires both continuous and episodic stimulation in response to the hormone prolactin following binding of prolactin to prolactin receptors on the mammary epithelial cell [76]. Initial differentiation of proliferating mammary epithelial cells to a fully functional, secreting cell-type is regulated by prolactin and is essential for lactogenesis (initiation of lactation) [21] to occur. Moreover, galactopoiesis (maintenance of established lactation) requires both continuous as well as episodic prolactin signaling [84]. During lactation, prolactin is primarily secreted by the anterior pituitary gland [41, 63, 64], and is responsible for maintaining a secretory phenotype [5, 76], increasing nutrient transport into the mammary gland [95] and ultimately regulating milk protein production and secretion [65, 85].

Circulating prolactin levels are very high during early lactation then decline as lactation proceeds. This pattern is positively associated with declining milk $\mathrm{Zn}$ concentrations throughout lactation [50], suggesting prolactin is involved in the secretion of $\mathrm{Zn}$ from the mammary gland. In fact, several studies directly implicate prolactin in the stimulation of $\mathrm{Zn}$ transport in mammary $[51,52]$ and prostate cells [18]. The mechanisms through which prolactin regulates $\mathrm{Zn}$ transport or $\mathrm{Zn}$ transporters are not currently understood. Zinc deficiency has been associated with hyperprolactinemia in men [3, 10, 69] and several in vitro studies have documented the inhibitory effects of physiological $\mathrm{Zn}$ concentrations on the synthesis and secretion of prolactin from the pituitary gland [9]. Zinc deficiency during lactation increases production and secretion of prolactin in rodents [12]. These observations may be at least partially responsible for the inverse relationship between low plasma $\mathrm{Zn}$ concentration and high milk $\mathrm{Zn}$ levels in women from developing countries as a reflection of restricted food intake [74] or malnutrition [67]. Taken together, data suggest that $\mathrm{Zn}$ itself may have a role in the in vivo regulation of prolactin release and thus play an indirect role in regulating $\mathrm{Zn}$ transporting mechanisms in hormonally responsive tissues.

The mechanisms through which prolactin exerts its biological activity are complex. During lactation, prolactin is secreted primarily by the pituitary gland and binds to the prolactin receptor hormonally responsive tissues such as the mammary gland initiating the Jak2/Stat5 [42, 109], ERK1/2 and p38 MAPK $[35,55]$ and protein kinase C [80] signaling cascades. The prolactin receptor-null mouse model has also identified phosphatidylinositol 3-kinase as another potential signaling mediator [8]. The prolactin receptor is expressed in numerous tissues, including the pituitary gland itself, where it may serve as the receiving end of a negative feedback loop [99]. The most wellestablished regulatory pathway involves Jak2 tyrosine kinase and the signal transducers and activators of transcription (Stats). Prolactin signaling can activate Stat5 protein homo-or heterodimerization and translocation into the nucleus whereby they bind to specific response elements (GAS sites) in the promoters of many genes. We have recently determined that one mechanism through which prolactin regulates $\mathrm{Zn}$ transporting mechanisms in the mammary gland results from the transcriptional control of ZnT2 through the Jak2/Stat5 signaling pathway through activation of two GAS elements in the ZnT2 promoter [92]. This may assist in increasing $\mathrm{Zn}$ secretion into milk. In 
Fig. 3 Prolactin stimulates the movement of ZnT2 from a peri-nuclear localization to an intracellularly dispersed compartment and $\mathrm{Zn}$ secretion in normal breast ( $\mathrm{HC} 11)$ cells. Cells were left untreated (a) or treated with prolactin $(\mathbf{b}, 1 \mu \mathrm{g} /$ $\mathrm{mL}$ ) for $30 \mathrm{~min}$ then fixed and permeabilized with Triton X-100. ZnT2 was detected with affinity purified ZnT2 antibody and visualized with anti-rabbit IgG conjugated to Alexa 488 (green). Nuclei were stained with TOPRO-3 (red). Images were collected at $\times 100$ under oil. c Treatment of HC11 cells with prolactin $(1 \mu \mathrm{g} / \mathrm{mL})$ that had been pre-loaded with ${ }^{65} \mathrm{Zn}$ stimulated ${ }^{65} \mathrm{Zn}$ secretion. (Data represent means \pm standard deviation, $n=6$ samples/time point)
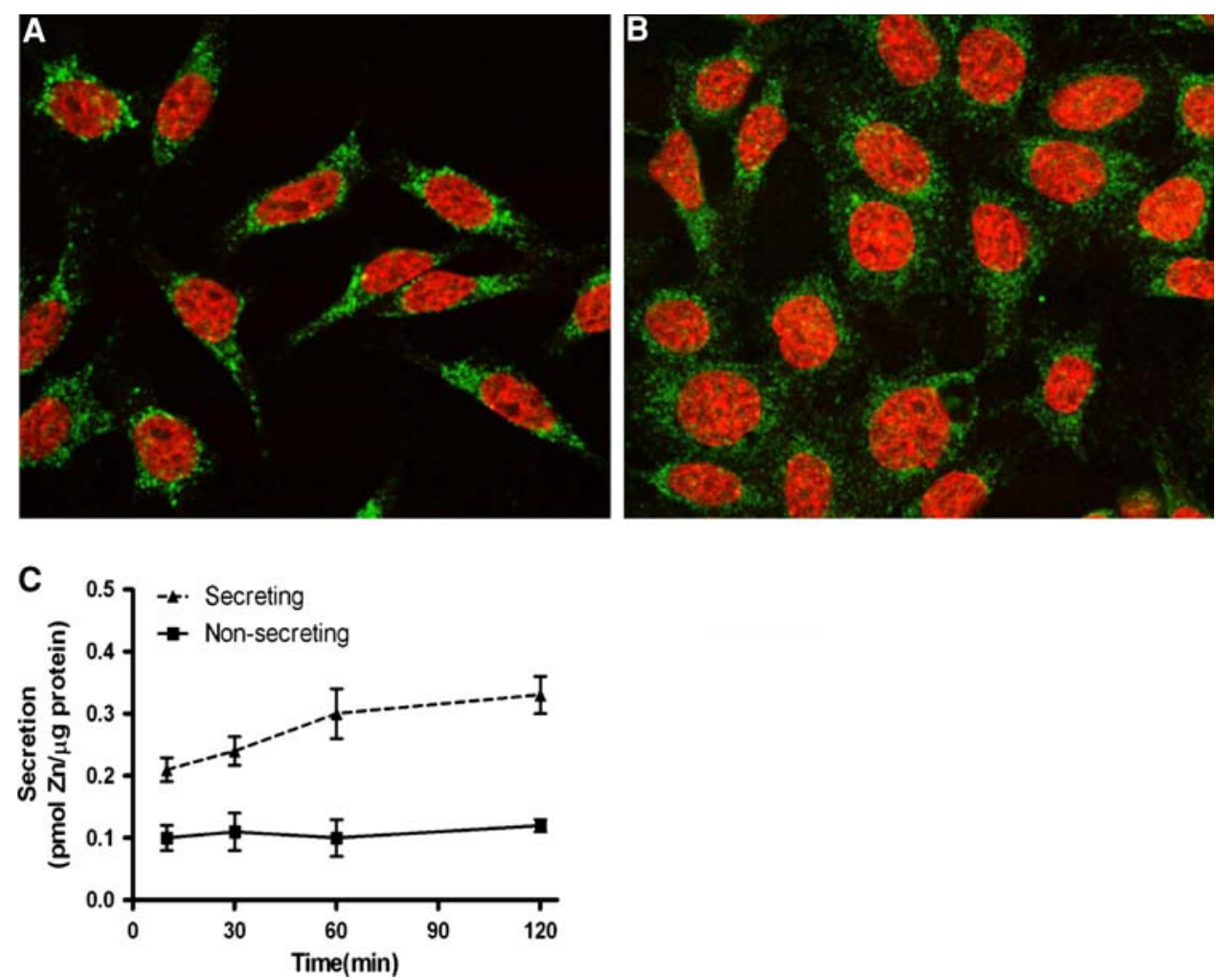

addition to the transcriptional regulation of $\mathrm{ZnT} 2$ by prolactin, it is conceivable that prolactin stimulation may transiently activate $\mathrm{Zn}$ transporting mechanisms as transient increases in prolactin secretion are responsible for the activation of acute secretory processes [84]. In fact, prolactin appears to post-translationally alter the sub-cellular localization of $\mathrm{ZnT} 2$ from a peri-nuclear compartment to the exocytotic vesicles of the secretory pathway (Fig. 3a, b) which is ultimately associated with increased $\mathrm{Zn}$ secretion (Fig. 3c). Understanding the mechanisms through which prolactin-stimulation affects $\mathrm{Zn}$ transporting processes is fundamental to our understanding of the complex integration of $\mathrm{Zn}$ transport regulation in hormonally responsive tissues such as the mammary and prostate glands.

\section{Mammary gland zinc metabolism and breast cancer}

Breast cancer is one of the leading causes of death among women with ductal carcinomas representing $\sim 30 \%$ of all diagnoses. The etiology of breast cancer is multifactorial and generally not understood; however, compelling evidence implicates dysregulated $\mathrm{Zn}$ homeostasis in breast cancer development [11, 17, 58, 73, 93]. While little is known regarding the relevance of dysregulated mammary gland $\mathrm{Zn}$ metabolism in breast cancer, biopsies taken from mastectomies or lumpectomies have revealed significantly higher $\mathrm{Zn}$ levels compared with normal breast tissue [32, 33, 73, 93]. Moreover, recent studies have found a correlation between high levels of $\mathrm{Zn}$ in breast tissue and the onset of carcinogenesis [19]. As previously mentioned, Zn homeostasis is a coordinated effort between members of the SLC39A and SLC30A gene families. The significance of dysregulated $\mathrm{Zn}$ transporting processes may reflect the fact that tight regulation of cellular $\mathrm{Zn}$ metabolism plays a regulatory role in modulating cell proliferation [68] and programmed cell death [15], processes which are uncoupled in cancer. Thus understanding the relationship between dysregulated $\mathrm{Zn}$ homeostasis and cellular function in breast cancer may provide important clues with respect to the prevention, diagnosis and management of breast cancer.

\section{Dysregulation in zinc transporting mechanisms}

Thus far, mounting evidence has linked dysregulation of $\mathrm{Zn}$ transporter abundance with the transition or progression of breast cancer. This postulate is evidenced by aberrant expression of proteins in breast cancer biopsies or cultured cells that are responsible for maintaining $\mathrm{Zn}$ homeostasis, such as metallothionein (MT) [43, 44], Zip6 [100], Zip7 [103], Zip8 [102] and Zip10 [45]. While these data implicate the importance of tight regulation of $\mathrm{Zn}$ transport in mammary gland function, we still lack specific 
information linking breast cancer etiology directly with either (1) abnormal $\mathrm{Zn}$ transport regulation; or (2) aberrant cellular functions resulting from dysregulated $\mathrm{Zn}$ transporter function.

Studies in animal models have begun to delineate the expression pattern and function of $\mathrm{Zn}$ homeostatic mechanisms on tumor growth. Studies using $N$-methyl- $N$ nitrosourea-induced mammary tumors in rats revealed that $\mathrm{Zn}$ concentrations in mammary tumors were 12-times higher than in normal mammary gland tissue, similar to what has been reported in biopsies of breast tissue from humans [57]. As a consequence MT mRNA and protein levels were significantly increased, similar to observations from breast biopsies from cancer patients [44, 48, 94]. Interestingly, MT mRNA expression has also been positively correlated with more aggressive and higher-grade tumors [30, 44]. This suggests that the severity of excess cellular $\mathrm{Zn}$ accumulation, perhaps as a consequence of decreased expression of critical $\mathrm{Zn}$ exporting or sequestering mechanisms such as ZnT1 [57] may exacerbate cellular dysfunction.

Most of our knowledge regarding the dysregulation of $\mathrm{Zn}$ transporters associated with breast cancer comes from studies in cultured cell models. Zip6 has been suggested to be prognostic marker for breast cancer [48, 98]. Studies in ZR-75-1 and MCF-7 human breast cancer cell lines [22, $26,70]$ and in normal mammary cells (Lopez and Kelleher, unpublished data) have demonstrated that Zip6 is positively regulated by estrogen suggesting that aberrant estrogen receptor signaling may play a modulating role in $\mathrm{Zn}$ metabolism dysregulation. Somewhat counter intuitively, studies have detected a negative correlation between Zip6 protein abundance and tumor size, grade and stage, implicating high Zip6 protein levels with less aggressive tumors [48]. In conjunction with these observations are reports demonstrating that Zip6 attenuation in breast cancer cells significantly increased cell growth and reduced cellcell interaction through reduced E-cadherin expression [96] further implicating Zip6 in "tumor suppression". Interestingly, elevated Zip6 mRNA levels have been associated with lymph node involvement and potentially metastatic spread [71, 72], illustrating the disconnect often observed between $\mathrm{Zn}$ transporter mRNA and protein abundance and the complex regulation of $\mathrm{Zn}$ transport regulation. Taken together, these data suggest that Zip6 plays a role in modulating breast cancer transition and/or metastasis; however, direct mechanisms through which this occurs requires further delineation.

Recently, Zip7 expression has been linked to abnormal cell growth. It has been observed that tamoxifen-resistant breast cancer cells have significantly increased intracellular $\mathrm{Zn}$ concentration compared with non-tamoxifen-resistant cells. This observation coincides with the over-expression of Zip7 and epidermal growth factor receptor (EGFR) activation [103]. It is interesting to note that activation of the EGFR has been implicated in the neoplastic transformation of solid tumors and over-expression of EGFR correlates with poor survival [6]. Attenuation of Zip7 expression diminished intracellular $\mathrm{Zn}$ levels and significantly reduced cell migration presumably through inactivation EGFR-mediated mechanisms [103]. Based on these data, the relationship between aberrant $\mathrm{Zn}$ influx and the activation of downstream cell signaling pathways in the pathogenesis of breast cancer is of critical interest and requires more examination. Finally, elevated Zip10 mRNA expression has been linked with lymph node metastasis and in highly invasive breast cancer cell lines such as MDAMB-231 and MDA-MB-435S [45]. In vitro, Zip10 gene attenuation and treatment with the Zn-chelator TPEN revealed diminished cell motility in MDA-MB-231 cells, supporting the essentiality of Zip10 for cell migration in breast cancer cells [45]. Beyond these cursory observations, we know little with respect to the underlying mechanisms or down-stream consequences. With that said, the significance of these findings begins to elucidate possible mechanisms by which alterations in cellular $\mathrm{Zn}$ metabolism as a result of dysregulation of $\mathrm{Zn}$ importers modulate oncogenesis. Taken together, these data suggest that $\mathrm{Zn}$ importers may play a significant role in the progression of breast cancer. More studies are critically needed to explore effects of anti-hormone therapies on $\mathrm{Zn}$ transporter regulation since these processes are largely hormonally regulated and anti-hormone therapy is the conventional breast cancer treatment.

\section{Downstream consequences of $\mathrm{Zn}$ dysregulation}

Understanding the down-stream effects of dysregulated $\mathrm{Zn}$ transport is critical to our understanding of the cellular processes that are affected and may provide important therapeutic interventions. One characteristic of cancerous cells is their inability to undergo programmed cell death or apoptosis. Zinc has been long appreciated to play important roles in cellular function, as both a deficiency and excess in cellular Zn level result in apoptosis [15]. Alterations in Zn homeostasis in breast cells likely dysregulates intrinsically mediated apoptogenic mechanisms. The intrinsic pathway of apoptosis is typically triggered following fluctuations in cellular microenvironment resulting in mitochondria damage. In support of the relationship between $\mathrm{Zn}$ and intrinsic apoptosis, recently, it has been shown that $\mathrm{Zn}$ chelation induced apoptosis in MCF-7 and MDA-MB468 breast cancer cells by promoting mitochondria permeability, cytochrome $\mathrm{C}$ release and activation of caspase- 9 activity [36]. Moreover, these effects were determined to be 
independent from the death-receptor dependent pathway [36]. Additionally, understanding effects of dysregulated $\mathrm{Zn}$ homeostasis on signaling events which are initiated upstream of apoptogenesis may be equally as critical as constitutive influx and/or the inability to modulate $\mathrm{Zn}$ efflux would activate a plethora of biological pathways. For example, Zn exposure increases ERK phosphorylation and cell viability in the breast cancer cell line MCF-7 and pretreatment with the ERK inhibitor PD98059 resulted in cell death through increased mitochondrial permeability [86]. This suggests that the over-expression of $\mathrm{Zn}$ importers may result in hyper-accumulation of $\mathrm{Zn}$ pools in breast cells and may play a role in suppressing apoptotic mechanisms increasing cell proliferation. An interesting question is which comes first; does increased cell proliferation increase cellular $\mathrm{Zn}$ requirements and consequently $\mathrm{Zn}$ import or does increased $\mathrm{Zn}$ import result in increased cellular proliferation? There is evidence that in $3 \mathrm{~T} 3$ cells (a fibroblast cell line) the initiation of cellular proliferation results in increased $\mathrm{Zn}$ retention, Zip1, ZnT1 and ZnT4 mRNA expression [97], supporting the concept that $\mathrm{Zn}$ transporter expression may be responding to increased cellular needs but not necessarily potentiating cellular $\mathrm{Zn}$ requirements in cancerous cells.

\section{Regulatory events}

Understanding the etiology of $\mathrm{Zn}$ transporter dysregulation may provide important therapeutic avenues. A relationship between estrogen and breast cancer has long been acknowledged and as a result anti-estrogen therapy is the primary endocrine treatment. Estrogen receptor alpha $(E R \alpha)$ is essential for estrogen-dependent cell growth, and its level of expression is a crucial determinant of response to endocrine therapy and prognosis in ER-positive breast cancer. Promoter analysis (http://www.cbil.upenn.edu/cgibin/tess/tess) reveals numerous ER $\alpha$ binding sites within the promoters of Zip1, Zip6, Zip7, Zip8 and Zip10. In fact, estrogen increased the expression of Zip1, Zip6, Zip8 and Zip10 in normal mammary cells (Fig. 4). Data indicate a positive association between Zip8 and Zip10 expression and treatment with the estrogen agonists tamoxifen and fluvestrant in MCF-7, MDA-MB-231 and MDA-MB-435S cells $[45,102]$, directly implicating estrogen-responsiveness with $\mathrm{Zn}$ importer expression. This suggests that the etiology of some breast cancers may reflect hormonal regulation of $\mathrm{Zn}$ metabolism and that endocrine therapies may uncouple $\mathrm{Zn}$ transporting mechanisms. This line of reasoning requires further delineation.

In addition to estrogen, several studies have described a direct correlation between hyperprolactinemia (abnormally high systemic prolactin level) and breast cancer [104];

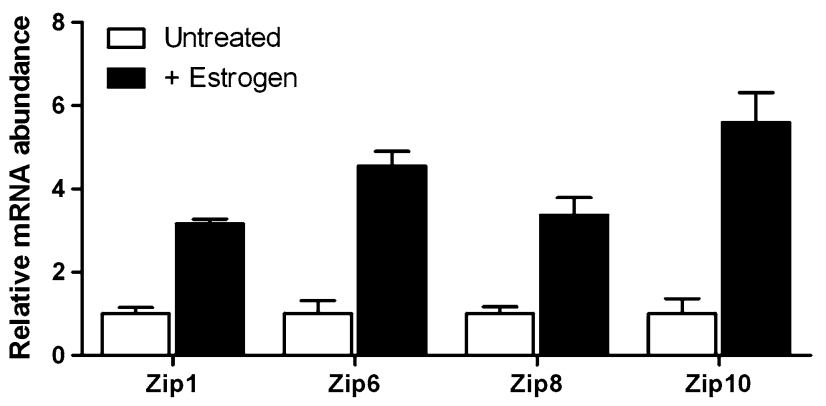

Fig. 4 Expression of $\mathrm{Zn}$ transporter mRNA is positively regulated by estrogen in normal breast cells (HC11). mRNA expression was measured by real-time PCR in cells treated with estrogen for $24 \mathrm{~h}$ and compared with untreated cells. Expression of Zip1, Zip6, Zip8 and Zip10 were elevated three- to sixfold relative to untreated cells. Data represent mean fold-change from untreated cells $(n=5$ samples per group, mean \pm standard deviation)

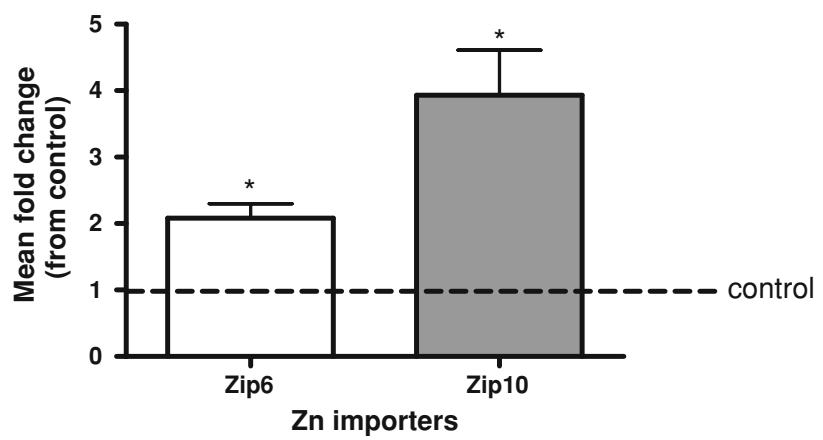

Fig. 5 Expression of $\mathrm{Zn}$ transporter mRNA is positively regulated by prolactin (PRL) in normal breast cells (HC11). mRNA expression was measured by real-time PCR in cells treated with PRL for $12 \mathrm{~h}$ and compared with untreated cells. Expression of Zip6 and Zip10 were elevated two- and threefold relative to untreated cells. Data represent mean fold-change from untreated cells $(n=3$ samples per group, mean \pm standard deviation)

however, the significance of this relationship is unknown. Prolactin is essential for mammary gland growth, differentiation and lactation [16, 28]. Most studies have focused on the role of prolactin in the regulation of cell signaling mechanisms directly associated with cell cycle control and apoptogenesis. As mentioned previously, prolactin plays a regulatory role in $\mathrm{Zn}$ homeostasis in normal mammary cells as Zn uptake and Zip3 and ZnT2 expression and localization are regulated at the transcriptional and post-translational level by prolactin $[51,52,66]$. Prolactin treatment of breast cells also increased the mRNA abundance of Zip6 and Zip10 (Fig. 5), suggesting a multifactorial and perhaps a potentiating effect of prolactin stimulation on $\mathrm{Zn}$ importing mechanisms. This effect is not limited to mammary cells. In fact, prolactin markedly stimulated the rapid uptake of $\mathrm{Zn}$ presumably by Zip1 in $\mathrm{LNCaP}$ and $\mathrm{PC}-3$ prostate cancer cells [18]. A consequence of increased $\mathrm{Zn}$ uptake may be cellular $\mathrm{Zn}$ accumulation as prolactin treatment results in the 
Fig. 6 Intracellular Zn pools in human tumorgenic T47D cells are increased in response to prolactin (PRL). Zinc accumulation was visualized by immunofluorescence using FluoZin-3 in cells treated with PRL (d-f) and compared with untreated cells $(\mathbf{a}-\mathbf{c})$. Prolactin significantly increased welldefined cellular $\mathrm{Zn}$ pools $(\mathbf{d}-\mathbf{f})$, compared with untreated cells $(\mathbf{a}-\mathbf{c})$

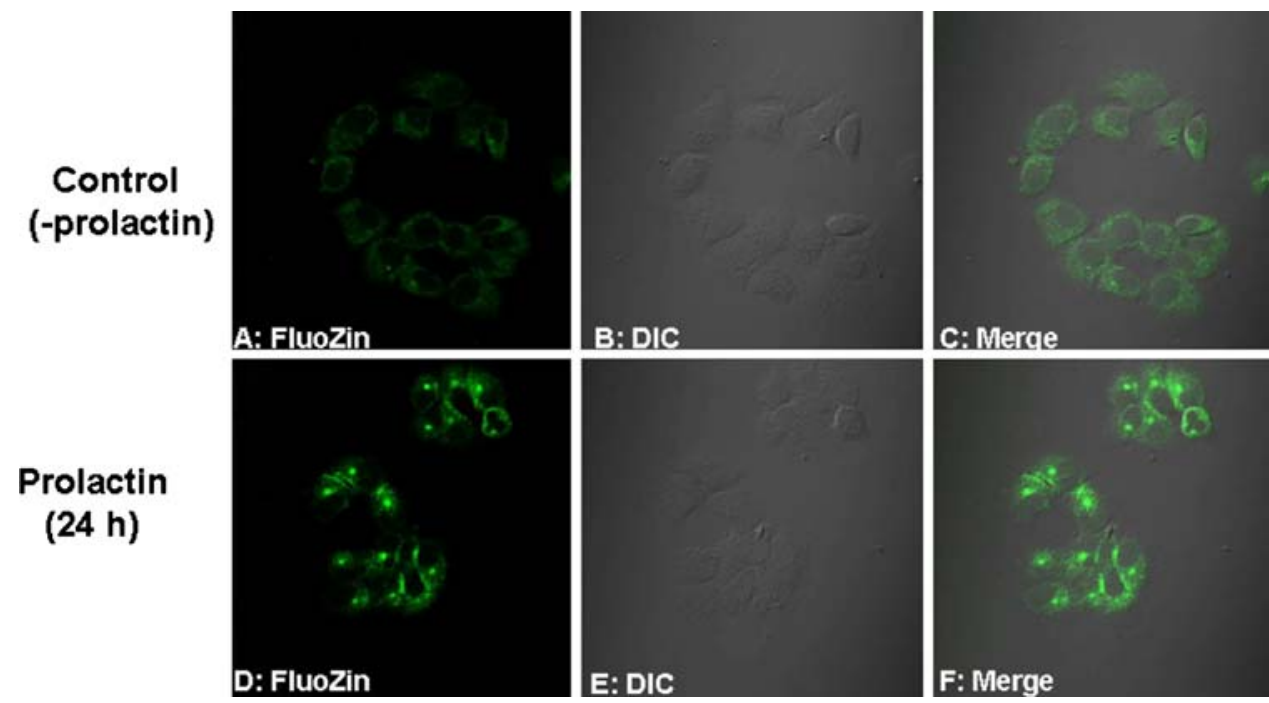

accumulation of cellular $\mathrm{Zn}$ pools in human tumorgenic breast (T47D) cells (Fig. 6). Clinical implications of these data reflect the fact that drugs which are widely prescribed for treatment of a range of mental and neurodegenerative illnesses including Parkinson's and depression (e.g. dopamine antagonists) secondarily increase prolactin levels, potentially increasing breast cancer risk in an extraordinary number of individuals. Together this suggests that hyperprolactinemia may potentiate the dysregulation of $\mathrm{Zn}$ metabolism observed in breast cancer cells.

\section{Concluding remarks}

In summary, the mammary gland is a highly specialized hormonally responsive tissue that has a unique requirement for $\mathrm{Zn}$ resulting from the need to import, redistribute and secrete an extraordinary amount of $\mathrm{Zn}$ into milk to provide optimal $\mathrm{Zn}$ to the newborn offspring. The uncoupling of this process during lactation results in severe $\mathrm{Zn}$ neonatal deficiency illustrating the essentiality of tight regulation of $\mathrm{Zn}$ transporting mechanisms in the mammary gland. Furthermore, the dysregulation of $\mathrm{Zn}$ transporting mechanisms in the non-lactating mammary gland may either result from or precipitate breast cancer transition or progression. The relationship between dysregulation of $\mathrm{Zn}$ transporting mechanisms and breast cancer may yield interesting avenues of investigation into novel therapeutic targets.

Conflict of interest The authors declare no conflict of interests.

\section{References}

1. Ackland ML, Mercer JF (1992) The murine mutation, lethal milk, results in production of zinc-deficient milk. J Nutr 122:1214-1218
2. Aggett PJ, Atherton DJ, More J, Davey J, Delves HT, Harries JT (1980) Symptomatic zinc deficiency in a breast-fed preterm infant. Arch Dis Child 55:547-550

3. Anttila PH, Dunkel L, Simell O (1987) Abnormal LH and prolactin responses in acrodermatitis enteropathica during hypozincaemia. J Inherit Metab Disord 10:196

4. Atkinson SA, Whelan D, Whyte RK, Lönnerdal B (1989) Abnormal zinc content in human milk. Risk for development of nutritional zinc deficiency in infants. Am J Dis Child 143:608-611

5. Ball RK, Friis RR, Schoenenberger CA, Doppler W, Groner B (1988) Prolactin regulation of beta-casein gene expression and of a cytosolic 120-kDa protein in a cloned mouse mammary epithelial cell line. EMBO J 7:2089-2095

6. Barr S, Thomson S, Buck E, Russo S, Petti F, Sujka-Kwok I, Eyzaguirre A, Rosenfeld-Franklin M, Gibson NW, Miglarese M, Epstein D, Iwata KK, Haley JD (2008) Bypassing cellular EGF receptor dependence through epithelial-to-mesenchymal-like transitions. Clin Exp Metastasis 25:685-693

7. Besecker B, Bao S, Bohacova B, Papp A, Sadee W, Knoell DL (2008) The human zinc transporter SLC39A8 (Zip8) is critical in zinc-mediated cytoprotection in lung epithelia. Am J Physiol Lung Cell Mol Physiol 294:L1127-L1136

8. Bole-Feysot C, Goffin V, Edery M, Binart N, Kelly PA (1998) Prolactin (PRL) and its receptor: actions, signal transduction pathways and phenotypes observed in PRL receptor knockout mice. Endocr Rev 19:225-268

9. Brandao-Neto J, Madureira G, Mendonca BB, Bloise W, Castro AV (1995) Endocrine interaction between zinc and prolactin. An interpretive review. Biol Trace Elem Res 49:139-149

10. Caticha O, Norato DY, Tambascia MA, Santana A, Stephanou A, Sarlis NJ (1996) Total body zinc depletion and its relationship to the development of hyperprolactinemia in chronic renal insufficiency. J Endocrinol Invest 19:441-448

11. Chakravarty PK, Ghosh A, Chowdhury JR (1986) Zinc in human malignancies. Neoplasma 33:85-90

12. Chowanadisai W, Kelleher SL, Lönnerdal B (2004) Maternal zinc deficiency raises plasma prolactin levels in lactating rats. J Nutr 134:1314-1319

13. Chowanadisai W, Lönnerdal B, Kelleher SL (2006) Identification of a mutation in SLC30A2 (ZnT-2) in women with low milk zinc concentration that results in transient neonatal zinc deficiency. J Biol Chem 281:39699-39707

14. Chowanadisai W, Lönnerdal B, Kelleher SL (2008) Zip6 (LIV1) regulates zinc uptake in neuroblastoma cells under resting but not depolarizing conditions. Brain Res 1199:10-19 
15. Clegg MS, Hanna LA, Niles BJ, Momma TY, Keen CL (2005) Zinc deficiency-induced cell death. IUBMB Life 57:661-669

16. Clevenger CV, Chang WP, Ngo W, Pasha TL, Montone KT, Tomaszewski JE (1995) Expression of prolactin and prolactin receptor in human breast carcinoma. Evidence for an autocrine/ paracrine loop. Am J Pathol 146:695-705

17. Costello LC, Feng P, Milon B, Tan M, Franklin RB (2004) Role of zinc in the pathogenesis and treatment of prostate cancer: critical issues to resolve. Prostate Cancer Prostatic Dis 7:111117

18. Costello LC, Liu Y, Zou J, Franklin RB (1999) Evidence for a zinc uptake transporter in human prostate cancer cells which is regulated by prolactin and testosterone. $\mathrm{J}$ Biol Chem 274:17499-17504

19. Cui Y, Vogt S, Olson N, Glass AG, Rohan TE (2007) Levels of zinc, selenium, calcium, and iron in benign breast tissue and risk of subsequent breast cancer. Cancer Epidemioll Biomarkers Prev 16:1682-1685

20. Desouki M, Geradts J, Milon B, Franklin RB, Costello LC (2007) hZip2 and hZip3 zinc transporters are down regulated in human prostate adenocarcinomatous glands. Mol Cancer 6:37-43

21. Desrivieres S, Prinz T, Laria NC-P, Meyer M, Boehm G, Bauer U, Schafer J, Neumann T, Shemanko C, Groner B (2003) Comparative proteomic analysis of proliferating and functionally differentiated mammary epithelial cells. Mol Cell Proteomics 2:1039-1054

22. Dressman MA, Walz TM, Lavedan C, Barnes L, Buchholtz S, Kwon I, Ellis MJ, Polymeropoulos MH (2001) Genes that cocluster with estrogen receptor alpha in microarray analysis of breast biopsies. Pharmacogenomics J 1:135-141

23. Dufner-Beattie J, Huang Z, Geiser J, Xu W, Andrews G (2006) Mouse ZIP1 and ZIP3 genes together are essential for adaptation to dietary zinc deficiency during pregnancy. Genesis 44:239251

24. Dufner-Beattie J, Langmade SJ, Wang F, Eide D, Andrews GK (2003) Structure, function and regulation of a subfamily of mouse zinc transporter genes. J Biol Chem 278:50142-50150

25. Eide DJ (2006) Zinc transporters and the cellular trafficking of zinc. Biochim Biophys Acta 1763:711-722

26. El-Tanani MK, Green CD (1997) Interaction between estradiol and growth factors in the regulation of specific gene expression in MCF-7 human breast cancer cells. J Steroid Biochem Mol Biol 60:269-276

27. Erway LC, Grider A Jr (1984) Zinc metabolism in lethal-milk mice. Otolith, lactation, and aging effects. J Hered 75:480-484

28. Freeman ME, Kanyicska B, Lerant A, Nagy G (2000) Prolactin: structure, function, and regulation of secretion. Physiol Rev 80:1523-1631

29. Gaither LA, Eide DJ (2000) Functional expression of the human hZIP2 zinc transporter. J Biol Chem 275:5560-5564

30. Gallicchio LM, Flaws JA, Fowler BA, Ioffe OB (2005) Metallothionein expression in invasive and in situ breast carcinomas. Cancer Detect Prev 29:332-337

31. Gao J, Zhao N, Knutson MD, Enns CA (2008) The hereditary hemochromatosis protein, HFE, inhibits iron uptake via downregulation of Zip14 in HepG2 Cells. J Biol Chem 283:2146221468

32. Geraki K, Farquharson MJ, Bradley DA (2002) Concentrations of $\mathrm{Fe}, \mathrm{Cu}$ and $\mathrm{Zn}$ in breast tissue: a synchrotron XRF study. Phys Med Biol 47:2327-2339

33. Geraki K, Farquharson MJ, Bradley DA (2004) X-ray fluorescence and energy dispersive X-ray diffraction for the quantification of elemental concentrations in breast tissue. Phys Med Biol 49:99-110
34. Girijashanker K, He L, Soleimani M, Reed JM, Li H, Liu Z, Wang B, Dalton TP, Nebert DW (2008) Slc39a14 gene encodes ZIP14, a metal/bicarbonate symporter: similarities to the ZIP8 transporter. Mol Pharmacol 73:1413-1423

35. Gutzman JH, Nikolai SE, Rugowski DE, Watters JJ, Schuler LA (2005) Prolactin and estrogen enhance the activity of activating protein 1 in breast cancer cells: role of extracellularly regulated kinase 1/2-mediated signals to c-fos. Mol Endocrinol 19:17651778

36. Hashemi M, Ghavami S, Eshraghi M, Booy EP, Los M (2007) Cytotoxic effects of intra and extracellular zinc chelation on human breast cancer cells. Eur J Pharmacol 557:9-19

37. He L, Girijashanker K, Dalton TP, Reed J, Li H, Soleimani M, Nebert DW (2006) ZIP8, member of the solute-carrier-39 (SLC39) metal-transporter family: Characterization of transporter properties. Mol Pharmacol 70:171-180

38. Huang L, Gitschier J (1997) A novel gene involved in zinc transport is deficient in the lethal milk mouse. Nat Genet 17:292-297

39. Huang L, Kirschke CP, Zhang Y, Yu YY (2005) The ZIP7 gene (Slc39a7) encodes a zinc transporter involved in zinc homeostasis of the Golgi apparatus. J Biol Chem 280:15456-15463

40. Iguchi K, Usui S, Inoue T, Sugimura Y, Tatematsu M, Hirano K (2002) High-level expression of Zinc Transporter-2 in the rat lateral and dorsal prostate. J Androl 23:819-824

41. Iwasaka T, Umemura S, Kakimoto K, Koizumi H, Osamura YR (2000) Expression of prolactin mRNA in rat mammary gland during pregnancy and lactation. J Histochem Cytochem 48:389396

42. Jahn GA, Daniel N, Jolivet G, Belair L, Bole-Feysot C, Kelly PA, Djiane J (1997) In vivo study of prolactin (PRL) intracellular signaling during lactogenesis in the rat: JAK/STAT pathway is activated by PRL in the mammary gland but not in the liver. Biol Reprod 57:894-900

43. Jin R, Bay B, Tan P, Tan BK (1999) Metallothionein expression and zinc levels in invasive ductal breast carcinoma. Oncol Rep 6:871-875

44. Jin R, Bay BH, Chow VT, Tan PH (2001) Metallothionein 1F mRNA expression correlates with histological grade in breast carcinoma. Breast Cancer Res Treat 66:265-272

45. Kagara N, Tanaka N, Noguchi S, Hirano T (2007) Zinc and its transporter ZIP10 are involved in invasive behavior of breast cancer cells. Cancer Sci 98:692-697

46. Kambe T, Narita H, Yamaguchi-Iwai Y, Hirose J, Amano T, Sugiura N, Sasaki R, Mori K, Iwanaga T, Nagao M (2002) Cloning and characterization of a novel mammalian zinc transporter, ZnT-5, abundantly expressed in pancreatic betacells. J Biol Chem 277:19049-19055

47. Kambe T, Yamaguchi-Iwai Y, Sasaki R, Nagao M (2004) Overview of mammalian zinc transporters. Cell Mol Life Sci 61:49-68

48. Kasper G, Weiser A, Rump A, Sparbier K, Dahl E, Hartmann A, Wild P, Schwidetzky U, Castaños-Vélez E, Lehmann K (2005) Expression levels of the putative zinc transporter LIV-1 are associated with a better outcome of breast cancer patients. Int J Cancer 117:961-973

49. Kelleher SL, Lönnerdal B (2002) Zinc transporters in the rat mammary gland respond to marginal zinc and vitamin A intakes during lactation. J Nutr 132:3280-3285

50. Kelleher SL, Lönnerdal B (2003) Zn transporter levels and localization change throughout lactation in rat mammary gland and are regulated by $\mathrm{Zn}$ in mammary cells. J Nutr 133:33783385

51. Kelleher SL, Lönnerdal B (2005) Molecular regulation of milk trace mineral homeostasis. Mol Aspects Med 26:328-339 
52. Kelleher SL, Lönnerdal B (2005) Zip3 plays a major role in zinc uptake into mammary epithelial cells and is regulated by prolactin. Am J Physiol Cell Physiol 288:C1042-C1047

53. King JC (2002) Enhanced zinc utilization during lactation may reduce maternal and infant zinc depletion. Am J Clin Nutr 75:23

54. Krebs NF (1998) Zinc supplementation during lactation. Am J Clin Nutr 68:509S-512S

55. Kumar S, Sathwara NG, Gautam AK, Agarwal K, Shah B, Kulkarni PK, Patel K, Patel A, Dave LM, Parikh DJ, Saiyed HN (2005) Semen quality of industrial workers occupationally exposed to chromium. J Occup Health 47:424-430

56. Langmade SJ, Ravindra R, Daniels PJ, Andrews GK (2000) The transcription factor MTF-1 mediates metal regulation of the mouse ZnT1 gene. J Biol Chem 275:34803-34809

57. Lee R, Woo W, Wu B, Kummer A, Duminy H, Xu Z (2003) Zinc accumulation in $N$-methyl- $N$-nitrosourea-induced rat mammary tumors is accompanied by an altered expression of ZnT-1 and metallothionein. Exp Biol Med 228:689-696

58. Li M, Zhang Y, Liu Z, Bharadwaj U, Wang H, Wang X, Zhang S, Liuzzi JP, Chang SM, Cousins RJ, Fisher WE, Brunicardi FC, Logsdon CD, Chen C, Yao Q (2007) Aberrant expression of zinc transporter ZIP4 (SLC39A4) significantly contributes to human pancreatic cancer pathogenesis and progression. Proc Natl Acad Sci USA 104:18636-18641

59. Liuzzi J, Lichten L, Rivera S, Blanchard R, Aydemir T, Knutson M, Ganz T, Cousins R (2005) Interleukin-6 regulates the zinc transporter Zip14 in liver and contributes to the hypozincemia of the acute-phase response. Proc Natl Acad Sci 102:6843-6848

60. Liuzzi JP, Blanchard RK, Cousins RJ (2001) Differential regulation of zinc transporter 1,2 and 4 mRNA expression by dietary zinc in rats. $\mathrm{J}$ Nutr 131:46-52

61. Liuzzi JP, Bobo JA, Cui L, McMahon RJ, Cousins RJ (2003) Zinc transporters 1,2 and 4 are differentially expressed and localized in rats during pregnancy and lactation. J Nutr 133:342351

62. Liuzzi JP, Bobo JA, Lichten LA, Samuelson DA, Cousins RJ (2004) Responsive transporter genes within the murine intestinal-pancreatic axis form a basis of zinc homeostasis. Proc Natl Acad Sci 101:14355-14360

63. Lkhider M, Delpal S, Bousquet MO (1996) Rat prolactin in serum, milk, and mammary tissue: characterization and intracellular localization. Endocrinology 137:4969-4979

64. Lkhider M, Delpal S, Le Provost F, Ollivier-Bousquet M (1997) Rat prolactin synthesis by lactating mammary epithelial cells. FEBS Lett 401:117-122

65. Lkhider M, Petridou B, Aubourg A, Ollivier-Bousquet M (2001) Prolactin signaling to milk protein secretion but not to gene expression depends on the integrity of the Golgi region. J Cell Sci 114:1883-1891

66. Lopez V, Kelleher SL (2009) Zinc transporter-2 (ZnT2) variants are localized to distinct sub-cellular compartments and functionally transport zinc. Biochem J (submitted)

67. Lunn PG, Austin S, Prentice AM, Whitehead RG (1984) The effect of improved nutrition on plasma prolactin concentrations and postpartum infertility in lactating Gambian women. Am J Clin Nutr 39:227-235

68. MacDonald RS (2000) The role of zinc in growth and cell proliferation. J Nutr 130:1500S-1508S

69. Mahajan SK, Hamburger RJ, Flamenbaum W, Prasad AS, McDonald FD (1985) Effect of zinc supplementation on hyperprolactinaemia in uraemic men. Lancet 2:750-751

70. Manning DL, Daly RJ, Lord PG, Kelly KF, Green CD (1988) Effects of oestrogen on the expression of a $4.4 \mathrm{~kb}$ mRNA in the ZR-75-1 human breast cancer cell line. Mol Cell Endocrinol 59:205-212
71. Manning DL, McClelland RA, Gee JM, Chan CM, Green CD, Blamey RW, Nicholson RI (1993) The role of four oestrogenresponsive genes, pLIV1, pS2, pSYD3 and pSYD8, in predicting responsiveness to endocrine therapy in primary breast cancer. Eur J Cancer 29A:1462-1468

72. Manning DL, Robertson JF, Ellis IO, Elston CW, McClelland RA, Gee JM, Jones RJ, Green CD, Cannon P, Blamey RW et al (1994) Oestrogen-regulated genes in breast cancer: association of pLIV1 with lymph node involvement. Eur J Cancer 30A:675678

73. Margalioth EJ, Schenker JG, Chevion M (1983) Copper and zinc levels in normal and malignant tissues. Cancer 52:868-872

74. McCrory MA, Nommsen-Rivers LA, Mole PA, Lönnerdal B, Dewey KG (1999) Randomized trial of the short-term effects of dieting compared with dieting plus aerobic exercise on lactation performance. Am J Clin Nutr 69:959-967

75. McMahon RJ, Cousins RJ (1998) Regulation of the zinc transporter ZnT-1 by dietary zinc. Proc Natl Acad Sci 95: 4841-4846

76. McManaman JL, Hanson L, Neville MC, Wright RM (2000) Lactogenic hormones regulate xanthine oxidoreductase and beta-casein levels in mammary epithelial cells by distinct mechanisms. Arch Biochem Biophys 373:318-327

77. Michalczyk A, Varigos G, Catto-Smith A, Blomeley RC, Ackland ML (2003) Analysis of zinc transporter, hZnT4 (Slc30A4), gene expression in a mammary gland disorder leading to reduced zinc secretion into milk. Hum Genet 113:202-210

78. Michalczyk AA, Allen J, Blomeley RC, Ackland ML (2002) Constitutive expression of hZnT4 zinc transporter in human breast epithelial cells. Biochem J 364:105-113

79. Milon B, Dhermy D, Poutney D, Bourgois M, Beaumont C (2001) Differential subcellular localization of hZip1 in adherent and non-adherent cells. FEBS Lett 507:241-246

80. Mitev V, Bayat-Sarmadi M, Lemnaouar M, Puissant C, Houdebine LM (1996) The effect of prolactin on casein kinase II, MAP kinase and PKC in rabbit mammary cells and $\mathrm{Nb} 2$ rat lymphoid cells. Biochem Pharmacol 52:1719-1727

81. Moore ME, Moran JR, Greene HL (1984) Zinc supplementation in lactating women: evidence for mammary control of zinc secretion. J Pediatr 105:600-602

82. Murgia C, Vespignani I, Cerase J, Nobili F, Perozzi G (1999) Cloning, expression, and vesicular localization of zinc transporter Dri 27/ZnT4 in intestinal tissue and cells. Am J Physiol 277:G1231-G1239

83. Murgia C, Vespignani I, Rami R, Perozzi G (2006) The Znt4 mutation inlethal milk mice affects intestinal zinc homeostasis through the expression of other $\mathrm{Zn}$ transporters. Genes Nutr $1: 61-70$

84. Neville MC, McFadden TB, Forsyth I (2002) Hormonal regulation of mammary differentiation and milk secretion. J Mammary Gland Biol Neoplasia 7:49-65

85. Ollivier-Bousquet M (1978) Early effects of prolactin on lactating rabbit mammary gland. Ultrastructural changes and stimulation of casein secretion. Cell Tissue Res 187:25-43

86. Ostrakhovitch EA, Cherian MG (2005) Inhibition of extracellular signal regulated kinase (ERK) leads to apoptosis inducing factor (AIF) mediated apoptosis in epithelial breast cancer cells: the lack of effect of ERK in p53 mediated copper induced apoptosis. J Cell Biochem 95:1120-1134

87. Palmiter RD, Cole TB, Findley SD (1996) ZnT-2, a mammalian protein that confers resistance to zinc by facilitating vesicular sequestration. EMBO J 15:1784-1791

88. Palmiter RD, Huang L (2003) Efflux and compartmentalizatin of zinc by members of the SLC30 family of solute carriers. In: Hediger MA (ed) The ABC of solute carriers, vol 447. Springer, New York. pp 744-751 
89. Parker PH, Helinek GL, Meneely RL, Stroop S, Ghishan FK, Greene HL (1982) Zinc deficiency in a premature infant fed exclusively human milk. Am J Dis Child 136:77-78

90. Pawan K, Neeraj S, Sandeep K, Kanta Ratho R, Rajendra P (2007) Upregulation of Slc39a10 gene expression in response to thyroid hormones in intestine and kidney. Biochim Biophys Acta 1769:117-123

91. Piletz JE, Ganschow RE (1978) Zinc deficiency in murine milk underlies expression of the lethal milk $(\mathrm{lm})$ mutation. Science 199:181-183

92. Qian L, Seo Y, Lopez V, Kelleher S (2009) ZNT2 is regulated by prolactin through activation of the JAK2-STAT5 signaling pathway. Am J Physiol Cell Physiol (sumitted)

93. Santoliquido PM, Southwick HW, Olwin JH (1976) Trace metal levels in cancer of the breast. Surg Gynecol Obstet 142:65-70

94. Schmid KW, Ellis IO, Gee JM, Darke BM, Lees WE, Kay J, Cryer A, Stark JM, Hittmair A, Ofner D et al (1993) Presence and possible significance of immunocytochemically demonstrable metallothionein over-expression in primary invasive ductal carcinoma of the breast. Virchows Arch A Pathol Anat Histopathol 422:153-159

95. Selvaraj NG, Omi E, Gibori G, Rao MC (2000) Janus kinase 2 (JAK2) regulates prolactin-mediated chloride transport in mouse mammary epithelial cells through tyrosine phosphorylation of $\mathrm{Na}^{+}-\mathrm{K}^{+}-2 \mathrm{Cl}$-cotransporter. Mol Endocrinol 14:2054-2065

96. Shen H, Qin H, Guo J (2009) Concordant correlation of LIV-1 and E-cadherin expression in human breast cancer cell MCF-7. Mol Biol Reprod 36:653-659

97. Simpson M, Xu Z (2006) Increased abundance of labile intracellular zinc during cell proliferation was due to increased retention of extracellular zinc in 3T3 cells. J Nutr Biochem 17:541-547

98. Srour N, Reymond MA, Steinert R (2008) Lost in translation? A systematic database of gene expression in breast cancer. Pathobiology 75:112-118

99. Suzuki T, Ishihara K, Migaki H, Matsuura W, Kohda A, Okumura K, Nagao M, Yamaguchi-Iwai Y, Kambe T (2005) Zinc transporters, ZnT5 and ZnT7, are required for the activation of alkaline phosphatases, zinc-requiring enzymes that are glycosylphosphatidylinositol-anchored to the cytoplasmic membrane. J Biol Chem 280:637-643

100. Taylor KM (2000) LIV-1 breast cancer protein belongs to new family of histidine-rich membrane proteins with potential to control intracellular $\mathrm{Zn}^{2+}$ homeostasis. IUBMB Life 49:249253

101. Taylor KM, Morgan HE, Johnson A, Hadley LJ, Nicholson RI (2003) Structure-function analysis of LIV-1, the breast cancerassociated protein that belongs to a new subfamily of zinc transporters. Biochem J 375:51-59

102. Taylor KM, Morgan HE, Smart K, Zahari NM, Pumford S, Ellis IO, Robertson JF, Nicholson RI (2007) The emerging role of the LIV-1 subfamily of zinc transporters in breast cancer. Mol Med 13:396-406

103. Taylor KM, Vichova P, Jordan N, Hiscox S, Hendley R, Nicholson RI (2008) ZIP7-mediated intracellular zinc transport contributes to aberrant growth factor signaling in antihormoneresistant breast cancer cells. Endocrinology 149:4912-4920

104. Tworoger SS, Hankinson SE (2008) Prolactin and breast cancer etiology: an epidemiologic perspective. J Mammary Gland Biol Neoplasia 13:41-53

105. Vallee BL, Falchuk KH (1993) The biochemical basis of zinc physiology. Physiol Rev 73:79-118

106. Wang F, Dufner-Beattie J, Kim BE, Petris MJ, Andrews G, Eide DJ (2004) Zinc-stimulated endocytosis controls activity of the mouse ZIP1 and ZIP3 zinc uptake transporters. J Biol Chem 279:24631-24639

107. Weaver BP, Dufner-Beattie J, Kambe T, Andrews GK (2007) Novel zinc-responsive post-transcriptional mechanisms reciprocally regulate expression of the mouse Slc39a4 and Slc39a5 zinc transporters (Zip4 and Zip5). Biol Chem 388:1301-1312

108. Weymouth RD, Kelly R, Lansdell BJ (1982) Symptomatic zinc deficiency in a premature infant. Aust Paediatr J 18:208-210

109. Winklehner-Jennewein P, Geymayer S, Lechner J, Welte T, Hansson L, Geley S, Doppler W (1998) A distal enhancer region in the human beta-casein gene mediates the response to prolactin and glucocorticoid hormones. Gene 217:127-139 